\title{
Islamic State in Yemen - A Rival to al-Qaeda?
}

\section{Maria-Louise Clausen}

Danish Institute for International Studies, http://www.diis.dk

\begin{abstract}
The Yemeni state has all but collapsed as the political transition that followed the popular protests in 2011 has been derailed. This has left Yemen without a functioning central government and thus provided a ripe context for the expansion of both al-Qaeda in the Arabian Peninsula (AQAP) and Islamic State in Yemen. This article focuses on the balance of power between AQAP and Islamic State in Yemen. Yemen is an interesting case of the international competition between al-Qaeda and Islamic State as the branch of al-Qaeda in Yemen, AQAP, is one of the strongest. The article argues that AQAP has sought to establish stronger local ties by enmeshing itself with the still strong tribal structures in Yemen whereas IS has sought to carve out a place for itself in Yemen by challenging AQAP on its religious zealousness, particularly by deepening sectarian divisions in Yemen.
\end{abstract}

Keywords: Islamic State, Yemen, al-Qaeda in the Arabian Peninsula, AQAP, Arab Spring, sectarianism.

\section{Introduction}

In Yemen, most people know of a hadith where the prophet Mohammed is said to have proclaimed that faith and wisdom are Yemeni. Now this hadith is used to call attention to the lack of wisdom displayed by current political leaders, who are described as egotistical and power-hungry. This same hadith is also being used in a rhetorical dispute between al-Qaeda on the Arabian Peninsula (AQAP) and Islamic State (IS) in Yemen, which since the beginning of 2015 have competed to represent Jihadism in Yemen. For instance, in issue seven of Dabiq, the IS English language magazine, it was used to underline the lack of 
wisdom exhibited by al-Qaeda's (AQ) Yemeni leadership. ${ }^{1}$ The principal target of the IS rhetoric is Harith al-Nadhari, a senior member of AQ in Yemen who publicly dismissed the expansion of the IS caliphate into Yemen. The most important criticism from IS is that $A Q$, led by Ayman al-Zawahiri, is too indulgent towards Shia Muslims. In this way IS is seeking to disseminate a narrative that AQAP has 'allowed' the Houthis-who are described as a Shia sect in league with Iran and the USA-to expand their power base in Yemen since the Arab Spring. This narrative is itself embedded in another, larger narrative, according to which Yemen is an example of AQ's inability to defend Sunni Muslims.

Yemen is renowned for being the home of one of the most active branches of $A Q$, and thus occupies a central position within the AQ movement. In 2013, the then emir of AQAP, Nasir al-Wuhayshi, who had previously been Osama Bin Laden's secretary, was appointed as Ayman Al-Zawahiri's second-in-command. Nasir al-Wuhayshi was killed in a drone strike in June 2015, but his successor, Qassim al-Raymi, was quick to affirm AQAP's continued loyalty to Al-Zawahiri and $A Q$. Yemen thus represents an interesting example of how IS is attempting to gain a foothold in an area in which a strong AQ organization is already established. IS was formally established in Yemen in November 2014, when the head of Islamic State, Abu Bakr al Baghdadi, accepted an oath of allegiance (bayah) from IS supporters in Yemen, which in the process became a province (wilayat) of Islamic State. ${ }^{2}$ At that point in time, IS in all likelihood consisted of a relatively small number of individuals, of which the majority are thought to have been defectors from AQAP. IS has attempted to appeal to sections of AQAP who feel that AQAP has been too hesitant to increase the brutality of its methods and intensify the sectarian narrative which has proven popular after the collapse of the Yemeni state following the Arab Spring in 2011. In this article, the focus is on how IS and AQAP distinguish themselves from one another, the balance of power between the two organizations, and their relationship with one another.

\section{The Arab Spring - The Collapse of the State of Yemen}

The Arab Spring reached Yemen at a time when Ali Abdullah Salih, the country's then president, was increasingly fighting to suppress growing dissatisfaction among large sections of the population. Under the slogans of the Arab Spring the hitherto isolated protests unified and grew until Yemen stood at the brink of civil war. At this point, the Gulf Cooperation Countries (GCC), supported by the United Nations (UN), helped successfully avoid civil war by formulating a negotiated transfer of power where Salih was forced to hand over the presidency to his vice-president, Abd Rabbuh Mansour Hadi, but granted immunity and allowed to remain in Yemen as head of the former ruling party,

\footnotetext{
1 Abū Maysarah ash-Shāmī, "The Qā’idah of Adh-Dhawāhirī, and An-Nadhārī, and the Absent Yemenī Wisdom," Dabiq, Issue 6 (1436 Rabi' al-Awwal): 16-25.

2 "Remaining and expanding," Dabiq, Issue 5 (1436 Muharram): 20-33.
} 
the General People's Congress (GPC). ${ }^{3}$ In addition to the transfer of executive powers from Salih to Hadi, the transitional agreement, commonly referred to as the GCC Initiative, provided for an inclusive National Dialogue aimed at defining the future Yemeni state and providing input to a new Yemeni constitution. The National Dialogue Conference (NDC), a 10-month-long dialogue with the participation of 565 representatives from various segments of Yemeni society, including most political parties, youths and women, was described as a success by Yemen's international partners. In particular, it was noted that the NDC had succeeded in bringing about political discussions between representatives of the existing political elite and groups which hitherto had not typically participated in the political process, including the Houthis. Simultaneously, the US intensified its drone campaign against AQAP with the full cooperation of president Hadi, and as recently as 2014, this willingness to cooperate led President Obama to praise Yemen as a model example in the fight against IS. ${ }^{4}$

Yet, while political representatives debated in the National Dialogue, the Houthi movement was engaged in armed conflict against members of the tribal and political elite north of the capital Sana'a. The Houthis, who are centered in the northern governorate of Sa'ada bordering Saudi Arabia (Fig. 1), have experienced decades of economic and political marginalization in Yemen. The Yemeni government and the Houthis, first led by Hussein al-Houthi and now by his son, Abd Malik al-Houthi, were engaged in six rounds of fighting from 2004 to $2010 .^{5}$ The decades of marginalization and fighting against the regime has shaped the Houthis into a battle-trained militia with little trust towards established elites in Yemen. This background helps understand how the Houthisalthough the sectarian narrative, in which the Houthis are Zaydi, a distinct branch of Shia-Muslims residing principally in Yemen, has grown in importance-initially drew substantial support in the capital Sana'a through an agenda focusing on the lack of economic development and increasing corruption. The Houthis had some credibility as an alternative to the established elites, which many saw as having hijacked the transition. Initially, the Houthis emphasized that they merely wanted to ensure that the decisions of the $\mathrm{Na}$ tional Dialogue were implemented, yet gradually they came to monopolize power. Through the course of the autumn of 2014, the political crisis in Yemen gradually escalated, while simultaneously groups such as AQAP succeeded in imbuing the crisis with an air of sectarianism.

3 The Gulf Cooperation Initiative and the Agreement on the Implementation Mechanism for the Transition Process in Yemen in Accordance with the Initiative of the Gulf Cooperation Council (GCC). Hadi was formally elected as president through a popular vote where he was the only candidate and took office on 21 February 2012 for a two-year transitional period.

4 "Statement by the President on ISIL," September 10, 2014, accessed January 15, 2017, www.whitehouse.gov/the-press-office/2014/09/10/statement-president-isil-1.

5 International Crisis Group, "The Huthis: From Saada to Sanaa," June 10, 2014, accessed January 15, 2017, https://www.crisisgroup.org/middle-east-north-africa/gulfand-arabian-peninsula/yemen/huthis-saada-sanaa. 


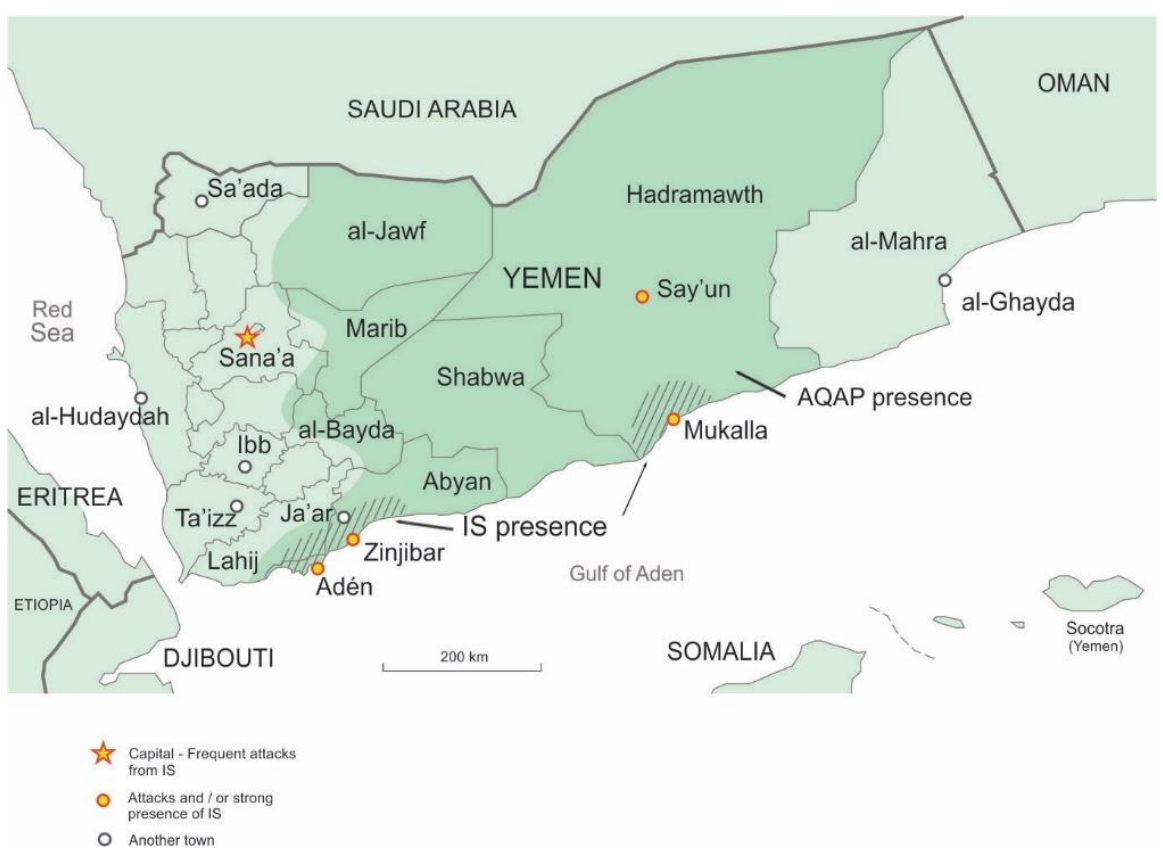

Figure 1: AQAP and IS presence in Yemen.

In March 2015, president Hadi was forced to flee Yemen. Shortly thereafter, at the request of president Hadi, the Saudi-led coalition began Operation Decisive Storm to restore peace and stability in Yemen. ${ }^{6}$ It is in this context that Islamic State has attempted to gain a foothold in Yemen, while AQAP has exploited the collapse of the central government and focus on the Houthis from international players, particularly Saudi Arabia, to expand into south-eastern Yemen.

\section{$A Q$ in Yemen - Exploiting Chaos}

Al-Qaeda on the Arabian Peninsula (AQAP) is the result of a merger between $A Q$ in Saudi Arabia and Yemen in 2009 and has since then made a name for itself as one of the most active branches of AQ. AQAP has been pointed to as the biggest direct terrorist threat to the US and, among others, has been linked to the 'underwear bomber,' a Nigerian national who received training in Yemen prior to attempting to detonate a specially-designed bomb affixed to his underwear on a flight to Detroit in December 2009, and most recently to the at-

6 UN Doc S/2015/217. See also, "Video: Saudi Ambassador in U.S. speaks on military campaign in Yemen," March 26, 2015, accessed January 16, 2017, http://english.alarabiya.net/en/webtv/reports/2015/03/26/Video-Saudi-

ambassador-in-U-S-speaks-on-military-campaign-in-Yemen.html. 
tack on the satirical magazine Charlie Hebdo in Paris in January $2015 .^{7}$ This has led the terrorism researcher, Thomas Hegghammer, to describe AQAP as possessing one of the most ambiguous enemy hierarchies of all the current Jihadist organizations, encompassing both domestic and international enemies by combining attacks against Western targets, in particular the US, with focus on local issues and attacks against the Yemeni regime. ${ }^{8}$ AQAP's attacks against international targets have raised its profile beyond the borders of Yemen, but the key to understanding the success of AQAP in Yemen lies in the organization's internal relations and its interactions with the Yemeni regime and other local groups.

AQAP's leadership is made up of experienced jihadists with decades of experience of armed warfare. The current emir, Qassim al-Raymi, received training in Afghanistan in the 1990s, after which he returned home to Yemen where he was imprisoned in 2004 for plotting an attack against various Western embassies. In 2006, together with the former emir of AQAP, Nasir al-Wuhayshi, alRaymi was part of a group of 23 inmates who broke out of one of Yemen's most secure prisons. This prison break breathed new life into AQ in Yemen. There has subsequently been a great deal of speculation as to whether the prison break may have been carried out with the aid of insiders within the prison organization, and that accordingly the Yemeni regime must have had knowledge of the imminent escape. Officially, the Yemeni regime worked together with the US in the War on Terror, but Salih did not necessarily view AQAP as a threat to the same degree as the US authorities. Nonetheless, Salih was aware that the military and economic aid the US provided to Yemen principally relied on the US belief that AQ constituted a terror threat. In Yemen it is widely held that Salih created or allowed AQAP to thrive in order to secure US economic and military aid. This aid was partly used to establish elite military units who were loyal to Salih personally.

AQAP is not a homogenous organization, but there has been a general focus on ensuring that the group is locally anchored. This anchoring has particularly happened through Ansar al-Shari'a (supporters of Shari'a), which is often described as a subgroup of AQAP and as having been established to overcome the negative associations evoked in Yemen by the name AQ. ${ }^{9}$ Ansar al-Shari'a focusses on domestic issues in Yemen, such as improving infrastructure by repairing roads, establishing electricity networks and distributing food, as well as restoring security to the country and reinstating law courts based on Shari'a

7 Gregory D. Johnson, "AQAP in Yemen and the Christmas Day Terrorist Attacks," CTC Sentinel, Special Issue (January 2010): 1-4.

8 Thomas Hegghammer, "The Ideological Hybridization of Jihadi Groups," Current Trends in Islamist ideology 7 (2009): 26-44.

9 Gregory D. Johnson, The Last Refuge. Yemen, al-Qaeda, and America's war in Arabia (New York: Norton, 2014), 272. 
law in areas in which the government has no presence or influence. ${ }^{10}$ While AQAP continues to focus on Western targets and spreading religious jurisprudence, Ansar al-Shari'a focusses to a far greater degree on winning local support by verbalizing and solving the practical problems faced by ordinary people.

In this way, AQAP has been able to achieve a certain degree of support from local tribes. AQAP's strategy is based on pragmatic acknowledgment that its success depends on local tribes accepting its presence. Despite the fact that tribal structures in Yemen have weakened, tribal leaders still have a central role and influence which can serve to facilitate or obstruct the spread of AQAP and likewise IS. On several occasions, AQAP has exploited the fragmentation of the Yemeni army following the transition of government in 2011 in order to plunder military installations, with the spoils being used to establish territorial control over larger or smaller areas. In 2011, AQAP took control of several towns and regions in two provinces in south-eastern Yemen: Abyan and Shabwa, including the regional capital, Zinjibar. This was accomplished without significant resistance because AQAP has traditionally had its main base of operations in these areas, and because of the almost complete absence of governmental institutions there. In 2012, the Yemeni army, supported by US drone strikes, regained control of these areas. Yet despite the fact that the Yemeni military formally took control, the Yemeni government was by no means able to ensure security in the area or the provision of basic amenities.

The Houthis took control of the capital Sana'a in September 2014 and from then on put President Hadi under steadily increasing pressure until he and his government stepped down in January 2015. In February, Hadi fled to the southern coastal town of Aden, and subsequently to the capital of Saudi Arabia, Riyadh, after the Houthis commenced their assault on Aden. On 24 March 2015, he asked the UN Security Council to pass a resolution which would pave the way for the establishment of a coalition of states willing to intervene against the Houthis in Yemen. A short time previously he had also asked the Arab League and the Gulf Cooperation Council (GCC) for immediate support, including military intervention, in order to beat back the Houthis. On March 26th, operation 'Decisive Storm' began. This was a military intervention carried out by a coalition led by Saudi Arabia, with logistical and intelligence support from the US and the United Kingdom. The Houthis' seizure of power, followed by the Saudi-led military intervention, resulted in the almost complete collapse of the Yemeni state, which presented AQAP with a prime opportunity to expand its sphere of influence. In April 2015, AQAP seized control of the strategically-important coastal town of Mukalla, which is Yemen's fifth-largest city and a key point of access for Yemen's oil industry. AQAP assumed control of Mukalla more or less unchallenged until May 2016, when the city was reconquered, primarily by troops from the United Arab Emirates. However, there are credible

${ }^{10}$ Christopher Swift, "Arc of Convergence: AQAP, Ansar al-Shari'a and the Struggle for Yemen," CTC Sentinel 5, no. 6 (June 2012): 1-6. 
accounts that indicate that AQAP withdrew without putting up any real resistance as a result of negotiations by local community leaders. ${ }^{11}$ In this way AQAP retained its operational capacity while being able to claim that it took the moral high ground by retreating and thereby avoiding a bloody and destructive battle in Yemen's fifth-largest city.

Nevertheless, although AQAP currently exerts more influence in Yemen than at any previous point in the country's history, this does not change the fact that, by all accounts, AQAP has limited public support from the people of Yemen. Opinions vary as to AQAP's numerical strength, but the organization probably consists of at most a few thousand members with links to a network of more loosely associated individuals and tribes, whose support to AQAP is primarily based upon a pragmatic assessment of possibilities for economic and political gain rather than genuine support for AQAP's overall cause. ${ }^{12}$ In a context where the Yemeni government is largely absent, local groups in some instances choose or are forced to accept AQAP's presence to the extent that the organization is able to improve security in the area, introduce a form of law and order, and offer basic local amenities such as water and electricity. There are, however, also Yemenis who support AQAP on the basis of AQAP's resistance to the Yemeni regime's collaboration with the US and in particular its drone policy. Yemen has seen more drone strikes since 2011 than almost any other country. ${ }^{13}$ Yet, although a number of AQAP leaders and notorious members of the organization have been killed-such as US citizen Anwar al-Awlaqi in 2011, who played a central role in spreading propaganda via the Internet by establishing the organization's first English-language magazine Inspire-AQAP has established a structure which is independent of individual leaders. The organization has thus been able to replace the leaders who have been killed, while the drone program serves to legitimize AQAP's continuing campaign against US interests and the Yemeni regime.

\section{Islamic State in Yemen}

Islamic State is a newcomer in the Yemeni context, having officially established itself in the country at the end of 2014. As reported in an account presented in issue 5 of Dabiq, Abu Bakr al-Baghdadi recognizes Yemen as a province (wilayat) of Islamic State. ${ }^{14}$ In the view of IS, this means that all existing organiza-

11 Elisabeth Kendall, "How can al-Qaeda in the Arabian Peninsula be defeated?", Washington Post, May 3, 2016, accessed January 16, 2017, www.washingtonpost.com/ news/monkey-cage/wp/2016/05/03/how-can-al-qaeda-in-the-arabian-peninsula-bedefeated/.

12 Alexandra Lewis, "Unpacking Terrorism, Revolution and Insurgency in Yemen: Real and Imagined Threats to Regional Security," Perspectives on Terrorism 7, no. 5 (2013): 77-92.

13 The Bureau of Investigative Journalism, Drone Strikes in Yemen, accessed February 26, 2017, https://www.thebureauinvestigates.com/projects/drone-war/yemen.

14 "Remaining and expanding," Dabiq, Issue 5 (1436 Muharram): 20-33. 
tions and groups in Yemen, including AQAP, are illegitimate and should submit to IS. The complete absence of a functioning state, combined with escalating violence and severe poverty and the fact that Yemen occupies a key strategic position on the Arabian Peninsula with a 1,800 km long border with Saudi Arabia, make it an obvious area of interest for IS. IS seeks to undermine Saudi Arabia's legitimacy as a protector of Islam's holy sites by describing the Saudi regime and its associated religious scholars as having strayed from the true faith. ${ }^{15}$ Yemen is therefore an obvious starting point for a more comprehensive military campaign on the Arabian Peninsula.

To begin with, a relative silence surrounded IS in Yemen. It was not until March 2015 that IS carried out a major attack. This attack was so significant, however, that it secured international attention. On Friday, 20 March IS carried out a coordinated suicide bombing of two mosques in Sana'a. The mosques which were mainly used by Zaydis, which is to say the form of Shia Islam practiced in Yemen which overlaps with the Houthi movement. Over 130 people died in the attacks. It is worth noting that AQAP immediately distanced itself from the attacks by making reference to the instructions set out by Ayman alZawahiri that religious sites must not be attacked. ${ }^{16}$ IS responded by describing AQAP as having a 'two-faced nature' and being guilty of double standards, since AQAP had earlier carried out an attack on a public pro-Houthi rally. ${ }^{17}$

Since then, IS has not carried out a suicide bombing on civilians on a similar scale, but the IS Wilayas in Sana'a, Aden-Abyan and Hadramawth have been active since the spring of 2015. To begin with, IS was particularly active in Sana'a, carrying out attacks on targets associated with the Houthi movement, including a number of attacks on mosques. Most recently, IS has concentrated on carrying out a series of attacks in southern and south-eastern Yemen, targeted at governmental institutions. In October 2015, IS attacked the al-Qasr Hotel, where members of Hadi's government in exile had established temporary headquarters. This led the then prime minister to leave Aden. In December 2015, IS assassinated the newly appointed governor of Aden, Jaafar Mohammed Saad, in a car bomb attack. These attacks underline president Hadi's lack of control over not only the country, but even over his own self-proclaimed temporary capital. It also demonstrates that IS has grown in strength under the smokescreen of the current conflict, with the focus of international powers concentrated on the Houthi movement - certainly up until the spring of 2016. Recently, IS has increasingly turned to undermining the security situation in southern Yemen. IS has targeted recruitment centers for the Yemeni army, including multiple attacks in Aden where at least 45 people were killed on 23

15 "Kill the Imams of Kufr," Dabiq, Issue 13 (1437 Rabi' al-Akhir): 6-8.

16 Thomas Jocelyn, "Analysis: Why AQAP quickly denied any connection to mosque attacks," The Long War Journal, March 20, 2015, accessed January 16, 2017, www.longwarjournal.org/archives/2015/03/analysis-why-aqap-quickly-denied-anyconnection-to-mosque-attacks.php.

17 "Soldiers of terror," Dabiq, Issue 8 (1436 Jumada al-Akhirah): 18-19. 
May as they queued to enlist and more than 60 were killed on 29 August. Similar attacks have been carried out in other cities such as Mukalla, where 25 army recruits were killed in May under similar circumstances. ${ }^{18}$

Yet despite the fact that IS clearly has the ability to carry out attacks in Yemen, it is estimated that it has fewer active members than AQAP, and that IS is less integrated into Yemeni society compared with its rival. While there are no reliable figures to confirm this, it is estimated that IS consists of a few hundred active members, with a hard core primarily made up of defectors from AQAP. $^{19}$

IS in Yemen has a centralized structure, Wilayat Yemen, but in addition consists of a number of sub-Wilayats, which identify themselves by adopting the names of existing provinces, such as Wilayat Hadramawth or Wilayat Sana'a. Officially, there are as many as ten different Wilayats in Yemen, but several of these have only been active to a limited extent, while the majority of IS attacks have been carried out in Sana'a, Abyan-Aden and Mukalla. In its organizational structure, IS is characterized by a greater degree of centralized authority and only limited acceptance of local autonomy. This has proved challenging to combine with the well-developed tradition of local autonomy and strong local identities that pertain in Yemen. For this reason, IS in Yemen, to a greater extent than AQAP, is perceived as a foreign organization and has not succeeded to date in integrating substantially with local tribal structures; indeed, it may not actively be seeking to do so. The Saudi-led military intervention has worsened the existing security vacuum in Yemen, and at the same time the Houthis' increasingly brutal methods have given the IS sectarian focus an increasing relevance. However, despite these factors, IS does not appear to have become a key player in Yemen. Moreover, within Wilayat Yemen, there has been criticism of IS' local leadership. This came to a head in December 2015, when more than 100 members, including several core members of IS, officially sought to replace the organization's regional leader (Wali) for Yemen. ${ }^{20}$ It is not certain to what extent IS possesses a functioning centralized chain-of-command in Yemen, and there are various theories as to the identity of its regional leader. This is perhaps due to the fact that the IS leadership is thought to consist chiefly of Saudis, among them Abu Bilal al-Harbi, a.k.a Nasser al-Ghaydani, who has been mentioned as possibly being the unpopular regional leader. The discontented IS

${ }^{18}$ Katherine Zimmerman and Jon Diamond, "Challenging the Yemeni State: ISIS in Aden and al Mukalla," Critical Threats, June 9, 2016, accessed January 16, 2017, http://www.criticalthreats.org/yemen/zimmerman-diamond-challenging-yemenistate-isis-in-aden-al-mukalla-june-9-2016.

19 Sami Aboudi, "Insight - In Yemen Chaos, Islamic State grows to rival al Qaeda," June 30, 2015, accessed January 16, 2017, http://uk.reuters.com/article/uk-yemensecurity-islamicstate-insight-idUKKCNOPA1T320150630.

20 Thomas Joscelyn and Bill Roggio, "More Islamic State members reject governor of Yemen Province," FDD's Long War Journal, December 28, 2015, accessed January 16, 2017, www.longwarjournal.org/archives/2015/12/more-islamic-state-membersreject-governor-of-yemen-province.php. 
members affirmed their loyalty to Abu Bakr al-Baghdadi, and thus the rejection of the IS leadership in Yemen should not be interpreted as a rejection of IS in its entirety. The criticism of the IS leader in Yemen was rejected by the IS central command and appears to have led to the exclusion of a number of members, but it is not clear what consequences the dissatisfaction within the organization will have for IS in Yemen.

IS has sought to gain a relative advantage over AQAP by intensifying the sectarian aspect of the current civil war in Yemen and escalating the brutality against the Houthis as well as against Yemeni security forces. IS has focused on suicide bombings and publication of various propaganda materials - which are professionally produced but do not necessarily require the resources of a particularly large organization-not to have the local Yemeni population as their primary readership. It is likely that, up to now, IS has functioned with a relatively high degree of international involvement, but this may change if IS succeeds in creating an image for itself as a more dynamic organization than AQAP.

\section{The relationship between AQAP and IS}

This section focuses on how IS distinguishes itself from AQAP and on the relationship between the two organizations. IS has sought to make a name for itself by attacking AQAP in two areas in particular: AQAP's more pragmatic approach to winning local support by focusing on setting up various local initiatives and initially displaying a small degree of flexibility with respect to the implementation of shari'a law; and AQAP's somewhat less brutal treatment of Yemen's Zaydi population in particular.

To begin with, AQAP adopted a relatively cautious approach to the IS declaration of Wilayat Yemen so as to avoid direct confrontation. For instance, on several occasions IS has been critical of AQAP in Dabiq, while AQAP has not mentioned IS in Inspire. This may reflect internal tensions within AQAP, which to a certain extent overlap with a generational divide, as a group of primarily younger members of AQAP have been inspired by IS successes in Syria and Iraq and have accordingly advocated a more aggressive strategy on the part of AQAP. AQAP has blamed IS for sowing discord between Muslims, but has otherwise been reserved in its criticism of IS. However, there is nothing to suggest that AQAP has any intention of dissolving itself in order to amalgamate with IS, and thus there will be a growing potential for conflict between IS and AQAP if IS continues to expand its activities in Yemen.

IS does not recognize AQAP as a legitimate organization in Yemen and has repeatedly attacked AQAP for compromising with respect to shari'a law. This is the case both domestically within Yemen and in international IS publications. For instance, issue 10 of Dabiq contains an account of how AQ in Yemen has chosen a different path to IS inasmuch as AQAP prioritizes "building ties with local groups and refraining from a strict application of Sharih, the legal code of Islam." The article is accompanied by an aerial view of the city of Mukalla, 
which AQAP at one time controlled, with the caption: "The City of Al-Mukalla in Yemen, where al-Qāi'dah made no effort to implement the Shari'ah after seizing control." ${ }^{\prime 1}$ IS does not control any territory in Yemen. However, in southern Yemen, where it has been most influential, IS has attempted to bring about a more strict interpretation of shari'a by means of threats and intimidation. For instance, IS has threatened to attack Aden University unless gender-segregated teaching is introduced.

AQAP has repeatedly managed to seize control of more or less extensive areas of Yemen, but this is more by virtue of the total collapse of the Yemeni state than of AQAP having developed a durable strategy for progressing from insurgency to maintaining territorial control. It is nonetheless illustrative of the balance of power between IS and AQAP that IS is (still) unable to seize control of territory in the same manner as AQAP. However, since October 2015 there has been an increase in insurgency activity, in particular in Wilayat Abyan-Aden and Wilayat Hadramawth, which may indicate the increasing influence of IS. ${ }^{22}$ This also means that, while the Houthis were initially the primary IS target, attacks are now aimed primarily on Yemen's security forces and politicians associated with president Hadi.

IS has moreover exploited the Houthi seizure of power in September 2014 and their subsequent attempt to gain control of Yemen in its entirety, to polarize the sectarian divide between Zaydis and Sunni Muslims in Yemen. The sectarian narrative is built on an inter-regional mistrust, which has its roots in the relationship between northern Yemen, where most Zaydis reside, and southern Yemen, which is predominantly Sunni. The Zaydis make up approximately 30$35 \%$ of Yemen's population. IS has challenged AQAP's self-appointed role as protectors of Sunni Muslims by calling attention to the fact that AQAP actions do not live up to their rhetoric, and by pointing out that IS would not have allowed the Houthis to achieve such leverage in Yemen. This is a crucial point, given that both organizations use religious legitimacy as a way of justifying their actions. AQAP is seeking to strike a balance between al-Zawahiri's precept that it must avoid excessive civilian casualties, while at the same time not presenting IS with the opportunity to position itself as the true defender of Sunni Muslims. In this way the sectarian narrative has become increasingly significant in Yemen. ${ }^{23}$

IS plays a role in the escalation of violence in Yemen through its more uncompromising approach to the local population. This appeals to certain elements within AQAP who are of the opinion that AQAP has been too cautious

21 "In the Words of the Enemy," Dabiq, Issue 10 (1436 Ramadan): 67.

22 Helene Lavoix, "Understanding the Islamic State system - Wilayat and Wali in Yemen," The Red (Team) Analysis Society, February 22, 2016, accessed January 16, 2017, https://www.redanalysis.org/2016/02/22/yemen-islamic-state/.

${ }^{23}$ Elisabeth Kendall, "Al-Qa'ida and Islamic State in Yemen: A Battle for Local Audiences," in Jihadism Transformed: Al-Qaeda and Islamic State's Global Battle of Ideas, ed. Simon Staffell and Akil Awan (London: Hurst Publishers, 2016), Chapter 4. 
and pragmatic. On account of this, IS has attracted defectors from AQAP. As a consequence, AQAP has likewise resorted to increasingly brutal methods and turned up the sectarian narrative, but it is also possible that the leadership of AQAP is not in full control of all sections of the organization, and that operations which appear to imitate the IS modus operandi are being carried out by followers of AQAP who have been inspired by IS propaganda videos. For example, this appears to be the case in the beheading of 14 soldiers in southern Yemen in August 2014.

The leadership of AQAP has in general sought to distance itself from the use of the extreme violence which characterizes IS activities, as this is considered to be a better long-term strategy for winning local support. For instance, in Sada al-Malahim, AQAP's Arabic language magazine which was published from 2008 to 2011, it was stated that a mujahid should abort an operation which would lead to the shedding of Muslim blood - an act which cannot be legitimized by reference to overriding rationales. ${ }^{24}$ This is a strategy which AQAP has developed over a long period of time, and one which manifested itself in December 2013, for instance, when AQAP carried out an attack on the Yemeni ministry of defense, which was alleged to house a drone command center. The same building complex housed a hospital, and when videos subsequently began to circulate showing the brutal shooting of healthcare workers and patients, AQAP apologized. It is not uncommon to hear Yemenis distance themselves from extremely violent attacks or attacks on civilians by claiming that the bulk of these attacks are carried out by 'foreign fighters.' This serves to illustrate the fact that many Yemenis struggle to reconcile Yemeni values with the actions of these organizations.

\section{Conclusion}

There has long been a tradition in Yemen of the political elite, especially the former president Salih, exploiting the threat of $A Q$ in order to secure Yemen access to military support - principally from the US. In the wake of the collapse of the Yemeni government, AQAP has expanded its sphere of influence, but simultaneously it faces a challenge in the form of a newly established IS organization, which seeks to capitalize on the current political chaos in Yemen by bringing about an escalation of violence. In this context, it is important that international powers do not indirectly overstate the threat of IS in Yemen, as has happened in the case of AQAP, and thereby give the Yemeni political elite a reason to present IS as a greater international threat than it in fact is.

While suicide bombings continue to be the primary IS strategy, several of these attacks have required additional resources and thus appear to indicate

24 Sada al-Malahim, no. 11 "Sunnat al-Ightiyial" (The Sunna (religious) ruling of Assassination). See Michael Page, Lara Challita, and Alistair Harris, "Al Qaeda in the Arabian Peninsula: Framing Narratives and Prescriptions," Terrorism and Political Violence 23, no. 2 (2011): 159. 
that IS may be in the process of consolidating its presence in Yemen. However, this does not change the fact that AQAP continues to be the dominant force in Yemen. AQAP's power base is rooted in the organization's ability to present itself as a means of achieving redress for areas which experienced decades of marginalization under Salih's regime. Thus, the best way to understand AQAP's strength and capacity for survival in Yemen is to consider the manner in which AQAP is able to verbalize and co-opt key local issues. IS, to a greater extent than AQAP, has a centralized command structure which has mainly attracted defectors from AQAP who are dissatisfied with AQAP's more protracted style of building up a terrorist organization. At the same time, IS in Yemen has prospered from the widespread narrative of IS as a victorious organization.

It is difficult to predict the future of IS in Yemen. IS is a direct rival to AQAP, but while rhetorical exchanges between the two groups have at times been pointed, they have yet to escalate into direct confrontation. However, it is conceivable that this will change if IS expands its activities in Yemen. At the same time, there is no doubt that the current civil war and the Saudi-led military intervention have exacerbated political and sectarian divisions to the point that both AQAP and IS have good opportunities to prosper in Yemen.

\section{About the author}

Maria-Louise Clausen is a post doc researcher at the Danish Institute for International Studies (DIIS). She holds a PhD in Political Science from the University of Aarhus and has studied political science, anthropology and Middle Eastern Studies at University of Southern Denmark, University of Richmond, and University of Copenhagen. She specializes in state-building interventions, particularly the interaction between internal and external actors with a geographical focus on the Middle East and Yemen in particular. Her current research focuses on Islamic State as an ideational challenge to the state-based international system, especially focusing on how Islamic State utilizes religious and cultural references to present itself as a more legitimate alternative to the nation-state. 